\section{AIDS test backlash}

\section{London}

THE Bulgarian government's compulsory AIDS screening programme has been attacked as undemocratic and a breach of human and civil rights by the Communist youth daily, Narodna Mladezh. The programme, introduced two years ago, imposes heavy fines on people who refuse to report for tests when ordered to do so and empowers the police to bring them in by force after a second refusal.

The first thrust of the programme was directed against 'high-risk' groups, in particular foreigners and Bulgarians who had spent more than a month abroad. As a result, the crews of Bulgarian ships returning home were marched off under armed guard to an "unknown destination" for testing. Journalists who questioned these tactics were asked to play such down such "mistakes" as being due to the tense situation that led to the programme, but the number of such incidents actually increased as the programme went on, according to Narodna Mladezh.

The screening process has now been extended to everybody in the capital, Sofia, between the ages of 16 and $65-$ just at the time when the Bulgarian national assembly is introducing legislation intended to democratize life and increase the individual's human and civil rights. Many doctors, the paper says, are opposed to compulsory screening; Dr Svetoslava Popova, head of the epidemiology section of the directorate of preventative health care and state public-health control says: "I do not want to comment on the screening. I hope that the results will soon show that it is more appropriate to stop it."

The World Health Organization, Narodna Mladezh points out, does not recommend mass screening, on the grounds that it is inefficient as a means of halting the spread of the human immunodeficiency virus (HIV), and expensive. (Each test, it says, costs around US\$1.00 plus the cost of the disposable hypodermic and needle.) If the Bulgarian government has "serious arguments" in support of mass screening, why are they being kept secret? A proper explanation, the paper urges, would "surely serve as one of our weapons against the disease".

Unfortunately, Narodna Mladezh undermines its case by failing to clarify its data. It gives the number of people tested, as of 1 May, as 100,000 and says that there has not been a single seropositive case. If these figures are correct, they must refer only to the Sofia screening programme. Nationwide, more than 1.5 million people (citizens and resident foreigners) have been tested, and up to 15 March, 71 were HIV-positive.

Vera Rich

\title{
Bombshell for life sciences
}

\section{Paris}

A MAJOR overhaul of French life sciences research is under way which could result in several research groups being closed down and resources concentrated at "centres of excellence". Last year, when French research minister, Hubert Curien, announced an increase in funding for the country's major civil research organisation, the Centre National de la Recherche Scientifique (CNRS), he made it clear that some "housekeeping" would be called for (see Nature 334, 579; 1988). Now, the recently nominated director of life sciences at CNRS, Claude Paoletti, has decided to apply Mr Curien's directive "exactly and with great determination".

For 1989, 284 new research posts were created within CNRS and laboratory running costs have nominally increased by 5.1 per cent. But in life sciences, which absorbs about a quarter of the FF9,700 million ( $\$ 1,500$ million) CNRS budget, this increase, for existing research groups, has been whittled to at most 0.6 per cent, once inflation has been taken into account. Some laboratories are even complaining that they have less money than last year. One group says that only 40 per cent of their research funds now comes from their 'employer', CNRS.

Although he criticizes the underfunding of CNRS life science research, Paoletti's 'new broom' approach is unequivocal and is dominated by two "absolute and unavoidable rules". First, researchers who are "lax" are likely to find their grants cut.

In the editorial of the latest CNRS lifesciences newsletter, Paoletti says that

\section{Animals released}

\section{Paris}

Two laboratories of the French national institutes of health and medical research (INSERM) at Lyons were broken into during the night of 20 May and more than 70 animals removed. About 40 macaque monkeys, 20 dogs, as wells as cats, rabbits and marsupials were taken, apparently causing some harm to the animals, according to an INSERM communique. The thieves, whose motives are still not known, also stole notebooks from the two laboratories - the vascular surgery and organ transplant unit directed by Mari-Rose Eloy and Marc Jeannerod's department of experimental neuropsychology.

The theft, says the communique, is "catastrophic" for the researchers, who were investigating newborn motor and visual handicap, Alzheimer's disease and cardiovascular prostheses. The affected laboratories conformed to the latest strict European regulations for animal experiments.

Peter Coles evaluation - in terms of publications, visits from foreign researchers, number of doctoral students and the number of patent applications - will ensure that "unjustified grants" will not be awarded. At a meeting of laboratory directors last week, Paoletti said that "some disciplines are dead. To inject more funds would be a waste of money". The CNRS only has a statutory duty "to provide researchers with a salary and a job, not the means to carry out research".

Second, he wants to "concentrate financial means on a diminishing number of research structures and on a restricted but better equipped and less dispersed population of researchers" - centres of excellence. The 'housekeeping' has already started. In January this year, Paoletti explained that the 306 laboratories would initially only receive 90 per cent of last year's budget and would have to apply for the rest. "Seventy per cent of laboratories", he says "will get their 10 per cent plus an extra 2 per cent. Some will get more than this, either because they are excellent or because they are working on urgent problems, or because they respond to a need for regionalisation". About 45 laboratories will end up with less than last year. "These are laboratories which I intend to demote and even, eventually, to close".

According to one laboratory director, researchers in life sciences are "very, very worried" about the new moves. The "lame duck" policy will hit hardest at the 227 socalled "associated laboratories" which operate within university departments rather than in autonomous centres. As many of these laboratories are in provincial areas, closures could leave regional universities with even less research capability in biology than at present - bad news for a government pushing a policy of decentralization. Curien does not favour the idea of centres of excellence, although he believes academically weak research departments should be closed.

Aware that cuts are unpopular, Paoletti has launched a campaign to claw back about FF1,000 million of the life-sciences budget automatically syphoned off each year to pay for expensive instruments, such as astronomical telescopes, that biologists do not use. Ten per cent of the global CNRS budget is reserved for these instruments, a 'tax' which is levied irrespective of discipline. Paoletti is adamant that this is unjust, especially as colleagues in the national medical research institutes do not have to pay a similar levy.

At the Paris meeting, Paoletti dropped several bombshells, including a suggestion that laboratory annual reports should be written in English. He made it clear that if his overall policy was not acceptable, he would resign.

Peter Coles 